\title{
Short Communication Bcl-2 expression in rituximab refractory cutaneous B-cell lymphoma
}

\author{
M Wobser', H Voigt', AO Eggert', R Houben', CS Kauczok', EB Bröcker' and JC Becker*,I \\ 'Department of Dermatology, University of Wuerzburg, Josef-Schneider-Strasse 2, 97080 Wuerzburg, Germany
}

\begin{abstract}
Rituximab has been established as an effective and safe therapy for cutaneous B-cell lymphoma (CBCL). Different survival pathways, that is the Raf/MEK/Erk- or the p38MAPK cascade, have been suggested as downstream mediators of rituximab and may be involved in treatment failure. Biopsies from four patients, suffering from different subtypes of CBCL, which were obtained at various time points of relapse during or after therapy with $375 \mathrm{mg}$ rituximab per $\mathrm{m}^{2}$ of body surface area, were analysed for the expression of CD20, CD3, Ki-67, Raf-kinase inhibitory protein (RKIP) and bcl-2 by immunohistochemistry. No CD20-loss variants, that is the suggested main tumour escape mechanism to rituximab therapy, were observed in any specimen of relapsing CBCL. Notably, the expression of proapoptotic RKIP remained increased in these tumour samples. This was concomitated by a constant to slightly reduced proliferation status as demonstrated by Ki-67 staining. However, relapsing CBCL exhibited a strong upregulation of the antiapoptotic molecule bcl-2 in comparison to pretherapeutic levels. The immunohistochemical analyses of this case series of rituximab refractory $\mathrm{CBCL}$ suggest that upregulation of bcl-2 may play a major role in therapy resistance.
\end{abstract}

British Journal of Cancer (2007) 96, I540-1543. doi:I0.1038/sj.bjc.6603762 www.bjcancer.com

Published online I May 2007

(c) 2007 Cancer Research UK

Keywords: cutaneous B-cell lymphoma (CBCL); rituximab; RKIP; bcl-2

Primary cutaneous B-cell lymphomas (CBCLs) generally show an indolent course. However, recurrences are observed in $25-68 \%$ of the patients (Servitje et al, 2002). For multilocular CBCL, systemic therapy with rituximab has evolved as an attractive therapeutic option.

The exact in vivo mechanisms of rituximab still remain elusive but likely include antibody-dependent cellular cytotoxicity (ADCC), complement-mediated lysis (CDC) and immune responses (Reff et al, 1994; Selenko et al, 2001). Furthermore, rituximab inhibits crucial survival pathways by upregulating the Raf-kinase inhibitory protein (RKIP), thus directly modifying the extracellular signal-regulated kinase1/2- and nuclear factor- $\kappa \mathrm{B}$, respectively (Jazirehi and Bonavida, 2005).

Despite a high initial response rate, local or distant recurrence of $\mathrm{CBCL}$ is frequently observed in rituximab therapy. To delineate possible factors predicting or being associated with relapse, we scrutinised recurrent CBCL from four patients before, during and after systemic rituximab therapy.

\section{PATIENTS AND METHODS}

\section{Patient characteristics}

Four patients with multifocal CBCL (classified according to the WHO-EORTC classification for primary cutaneous lymphoma

*Correspondence: Professor Dr JC Becker;

E-mail: Becker_CC@klinik.uni-wuerzburg.de

Revised 19 February 2007; accepted 2 April 2007; published online I May 2007
(Willemze et al, 2005)) were treated with rituximab intravenously at doses of $375 \mathrm{mg} \mathrm{m}^{-2}$ body surface area at the Department of Dermatology (University of Wuerzburg, Germany). For patient characteristics see Table 1. Before therapy and at different time points after initiation of therapy, skin biopsies were taken to confirm the diagnosis and to allow further work-up. Patients provided informed consent before any of these analyses.

\section{Immunohistochemistry}

Tissue specimen from cutaneous sites of lymphoma were obtained by surgical excision, immediately fixed in formalin and embedded in paraffin. Deparaffinisation, antigen retrieval (s1699, Dako, Hamburg, Germany), endogenous peroxidase blocking and washing procedures were performed according to standard protocols. For staining, slides were incubated for $60 \mathrm{~min}$ with a murine anti-CD20 polyclonal antibody (Clone L26, Dako), a murine anti-CD3 polyclonal antibody (Clone 17A2, BD, Heidelberg, Germany), Ki-67 (Clone M7240, Dako), a rabbit anti-RKIP polyclonal antibody (Upstate Biotechnology, Lake Placid, NY, USA) or for 25 min with a murine anti-bcl-2 polyclonal antibody (Clone 124, Dako). Visualisation was performed with Multi Link Biotin Kit and Streptavidin HRP (K0690) and Vector Nova Red (Vector SK-4800, Linaris, Wertheim, Germany) according to the manufacturers' protocol. Evaluation was performed by two independent histologists.

\section{RESULTS}

To this end, we analysed the presence of CD20 expression itself, as well as that of major intracellular downstream targets of rituximab 
Table I Patient characteristics of four patients exhibiting relapse under therapy with intravenous rituximab $375 \mathrm{mg} \mathrm{m}^{-2}$ of body surface area

\begin{tabular}{|c|c|}
\hline Patients & 4 \\
\hline \multicolumn{2}{|l|}{ Gender } \\
\hline Male & । \\
\hline Female & 3 \\
\hline Age (years) & $\begin{array}{c}\text { Mean: } 67 \pm 6 \\
\text { Range: } 68-72\end{array}$ \\
\hline \multicolumn{2}{|l|}{ Prior therapy } \\
\hline Excision & I \\
\hline Radiotherapy & । \\
\hline Oral antibiotics & I \\
\hline Local steroids & । \\
\hline Other & I \\
\hline None & 0 \\
\hline \multicolumn{2}{|l|}{ Concomitant therapy } \\
\hline Excision & 4 \\
\hline Radiotherapy & । \\
\hline Chemotherapy & I \\
\hline Other & 0 \\
\hline None & 0 \\
\hline \multicolumn{2}{|l|}{ Subsequent therapy } \\
\hline Excision & 3 \\
\hline Radiotherapy & 2 \\
\hline Chemotherapy & । \\
\hline Intralesional rituximab & । \\
\hline Other & I \\
\hline None & 0 \\
\hline \multicolumn{2}{|l|}{ Histology of primary diagnosis } \\
\hline $\mathrm{FBCL}$ & 2 \\
\hline LBCL & 2 \\
\hline \multicolumn{2}{|l|}{ Best response to rituximab } \\
\hline CR & 3 \\
\hline PR & । \\
\hline SD & 0 \\
\hline PD & 0 \\
\hline Time to relapse (months) & $\begin{array}{c}\text { Mean: } 9 \pm 8 \\
\text { Range: } 0-24\end{array}$ \\
\hline \multicolumn{2}{|c|}{ Best response to following therapy } \\
\hline CR & 3 \\
\hline PR & 0 \\
\hline SD & 0 \\
\hline PD & 0 \\
\hline Follow-up (years) & $2 \pm 1$ \\
\hline \multicolumn{2}{|l|}{ Current status } \\
\hline Alive with disease & । \\
\hline Alive without disease & 3 \\
\hline Died of lymphoma & 0 \\
\hline Died of unrelated cause & 0 \\
\hline
\end{tabular}

by immunohistochemistry. We refrained from quantitative PCR analyses to avoid data confounding by the expression profile of inflammatory bystander cells in B-cell lymphoma infiltrates which can be excluded by morphological analysis in immunohistochemistry. The quantitative evaluation of RKIP and bcl-2 expression was performed in tumour cell-enriched areas of CBCL, as determined by $\mathrm{CD} 3$ staining for detecting infiltrating $\mathrm{T}$ lymphocytes (Figure 1A).

At the time of first diagnosis, all tumours consisted of predominantly CD20-positive malignant lymphocytes (Table 2,
Figure 1D). Recurrent disease demonstrated in nearly all patients a persistent CD20 expression (Figure 1F). A transient minor CD20 downregulation was observed in only one single biopsy (Table 2, Figure 1E).

The expression of proapoptotic RKIP in tissue specimen of patients before therapy with rituximab, was detectable only in few lymphoma cells (Table 2, Figure 1G). However, RKIP was remarkably upregulated in virtually all relapsed lymphoma specimen during or after therapy (Figure $1 \mathrm{H}$ and I). Indicative for proapoptotic and antiproliferative properties of upregulated RKIP, the proliferation status of B-cell lymphoma cells remained at least constant to slightly reduced under rituximab therapy (Figure $1 \mathrm{~B}$ and $\mathrm{C}$ ).

Bcl-2 expression was detected in all lymphoma specimen before therapy (Table 2), albeit only with a low to moderate intensity (Figure 1J). Notably, however, the expression of bcl-2 was consistently increased in relapsing disease (Figure $1 \mathrm{~K}$ and $\mathrm{L}$ ).

\section{DISCUSSION}

The observed upregulation of proapoptotic RKIP in situ during rituximab therapy is likely to represent the direct intracellular signalling properties of rituximab (Vega et al, 2004; Jazirehi and Bonavida, 2005). RKIP belongs to the family of the metastasis suppressor genes, which inhibit cellular proliferation, growth and metastatic spread and induce apoptosis (Keller et al, 2005). Nevertheless, we observed rituximab refractory relapse in our patient cohort despite an overexpression of RKIP.

Different factors may contribute to this therapeutic failure of CD20-targeted therapies, including CD20 downregulation (Foran et al, 2001), altered signal transduction pathways (Pommier et al, 2004), circulating CD20 protein (Manshouri et al, 2003), polymorphisms in the Fc $\gamma$ RIII receptor (Cartron et al, 2002) and an increase in complement-resistant proteins like CD55 or CD59 (Treon et al, 2001; Manches et al, 2003). The immunohistochemical analysis of the presented case series of relapsing CBCL lesions revealed an unchanged CD20 expression. In contrast, a highly increased bcl-2 expression in recurrent lesions was observed, thus providing an alternative explanation for treatment failure. The overexpression of proapoptotic factors, eg Mcl-1, bcl-2 or bcl-xL, has been implicated in cancer development, tumour progression and therapy resistance of B-cell lymphoproliferative diseases (Bannerji et al, 2003). The regulation of bcl-2 expression underlies a complex network of environmental stimuli, combined with altered signal transduction in lymphoma cells - which may abrogate the proapoptotic properties of rituximab and contribute to the observed therapeutic failure (Pommier et al, 2004). Interestingly, the relapsed CBCL in our patient cohort responded to other subsequent treatment modalities despite upregulation of bcl-2. Sensitisation to subsequent therapy may be conveyed by a counteracting downregulation of other antiapoptotic proteins by rituximab signalling; in this context, the observed increased expression of RKIP may be of importance, as it also functions as a negative regulator of antiapoptotic bcl-xL (Vega et al, 2004; Jazirehi and Bonavida, 2005). Hence, a complex network of interacting regulators of apoptosis is likely to be influenced by rituximab and the balance between pro- and antiapoptotic factors may determine the clinical outcome.

In summary, our results - albeit confined to a limited number of patients and the analysis of only two pro- or antiapoptotic signalling pathways, namely RKIP and bcl-2 - raise the hypothesis that the modulation of regulators of apoptosis may be important for the clinical effect of rituximab on CBCL. A more complex analysis of different signalling pathways, which includes potential cross-talks among apoptosis-regulating proteins in a larger patient cohort and parallel in vitro experiments, is warranted to establish the exact modus operandi of rituximab besides CDC and ADCC. 

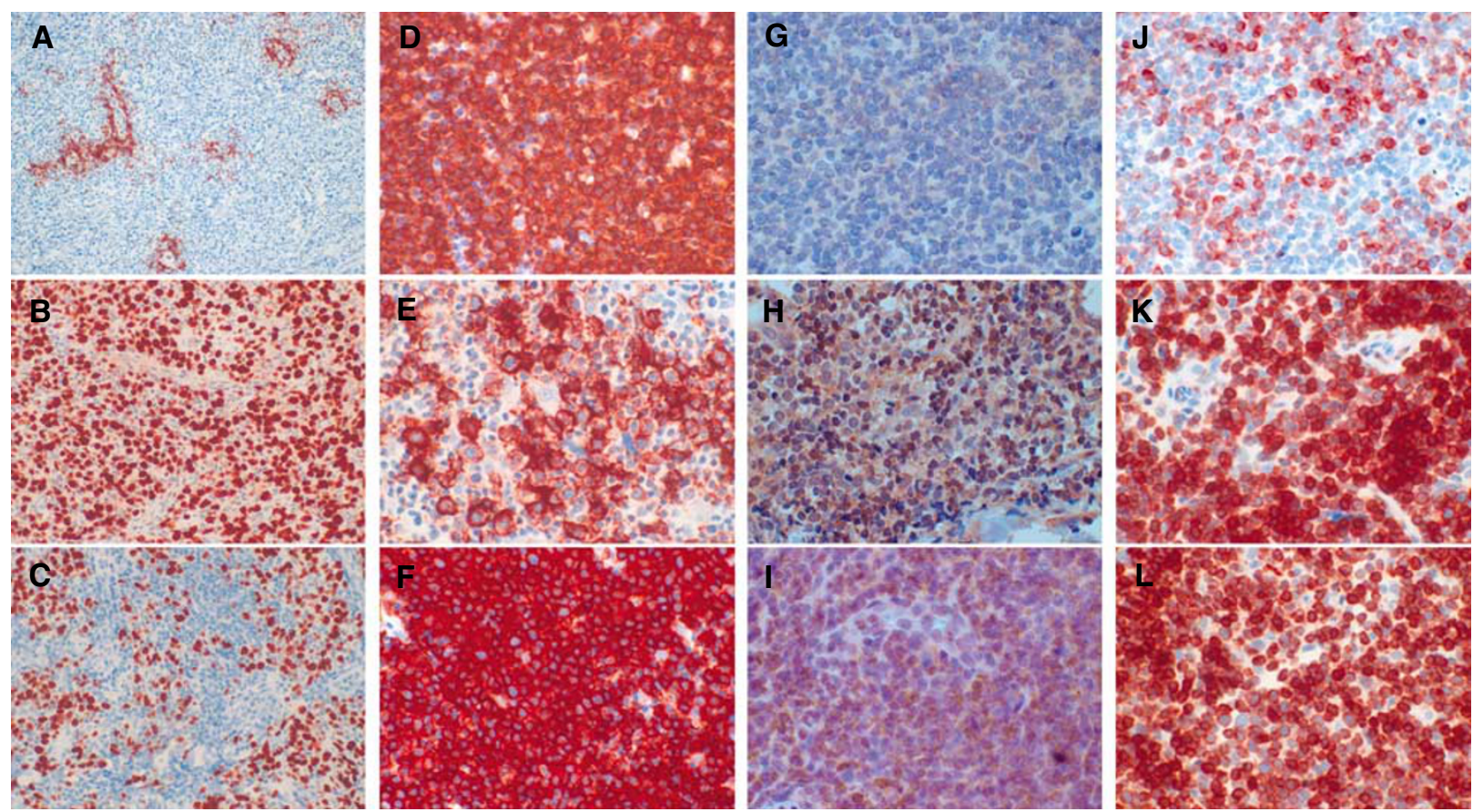

Figure I (A) CD3 + infiltrating T-lymphocytes surrounding the follicular CBCL lesion. Magnification $\times$ I0. (B and $\mathbf{C})$ Proliferation status of the tumour cells as determined by ki-67 staining before $(\mathbf{B})$ and during $(\mathbf{C})$ therapy with rituximab. Magnification $\times 20$. (D-F) Expression status of CD20 in relapsed $\mathrm{CBCL}$ before $(\mathbf{D})$ and during $(\mathbf{E}$ and $\mathbf{F})$ rituximab treatment. Magnification $\times 40$. ( $\mathbf{G}-\mathbf{I})$ RKIP expression at primary diagnosis $(\mathbf{G})$ and during $(\mathbf{H}$ and $\mathbf{I})$ therapy with rituximab. Magnification $\times 40$. (J-L) Expression of antiapoptotic bcl-2 in recurring $C B C L$ at diagnosis $(\mathbf{J})$ and during rituximab application $(\mathbf{K}$ and $\mathbf{L})$. Magnification $\times 40$.

Table 2 CD20, RKIP and bcl-2 expression levels in specimen of cutaneous lymphoma relapse obtained at different time points since treatment start

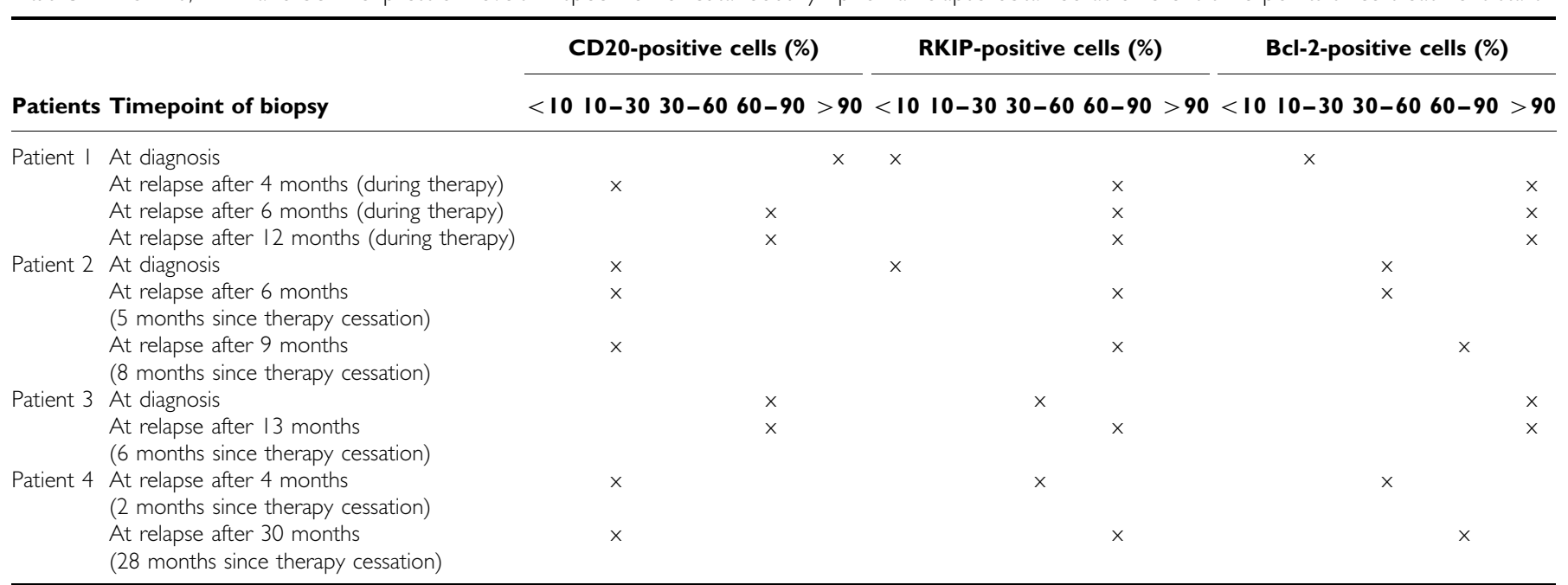

RKIP = Raf-kinase inhibitory protein. Repetitive biopsies were obtained either during (patient I) or after (patients 2 -4) rituximab therapy.

\section{ACKNOWLEDGEMENTS}

M Wobser is responsible for the conception and design of the work, the provision of study material, collection and assembly of data, data analysis and interpretation and manuscript writing. H Voigt is involved in collection and assembly of data, data analysis and interpretation and final approval of the manuscript. AO Eggert is responsible for provision of study material, collection and assembly of data and has finally approved the manuscript. $\mathrm{R}$ Houben is responsible for data analysis and interpretation and final approval of the manuscript. CS Kauczok is involved in the provision of study material, in the collection of histological specimen and data analysis and final approval of the manuscript. EB Bröcker is responsible for the conceptional design and the final approval of the manuscript. J C Becker is responsible for the conceptional design, data analysis and interpretation, manuscript writing and final approval of the manuscript.

We do not have any conflicts of interest and concur with the submission and being listed as an author on the paper. We are thankful for the excellent technical assistance of Claudia Siedel. This work was supported in part by the KFO124. 


\section{REFERENCES}

Bannerji R, Kitada S, Flinn IW, Pearson M, Young D, Reed JC, Byrd JC (2003) Apoptotic-regulatory and complement-protecting protein expression in chronic lymphocytic leukemia: relationship to in vivo rituximab resistance. J Clin Oncol 21: 1466-1471

Cartron G, Dacheux L, Salles G, Solal-Celigny P, Bardos P, Colombat P, Watier H (2002) Therapeutic activity of humanized anti-CD20 monoclonal antibody and polymorphism in IgG Fc receptor FcgammaRIIIa gene. Blood 99: 754-758

Foran JM, Norton AJ, Micallef IN, Taussig DC, Amess JA, Rohatiner AZ, Lister TA (2001) Loss of CD20 expression following treatment with rituximab (chimaeric monoclonal anti-CD20): a retrospective cohort analysis. Br J Haematol 114: $881-883$

Jazirehi AR, Bonavida B (2005) Cellular and molecular signal transduction pathways modulated by rituximab (rituxan, anti-CD20 mAb) in nonHodgkin's lymphoma: implications in chemosensitization and therapeutic intervention. Oncogene 24: $2121-2143$

Keller ET, Fu Z, Brennan M (2005) The biology of a prostate cancer metastasis suppressor protein: Raf kinase inhibitor protein. J Cell Biochem 94: 273-278

Manches O, Lui G, Chaperot L, Gressin R, Molens JP, Jacob MC, Sotto JJ, Leroux D, Bensa JC, Plumas J (2003) In vitro mechanisms of action of rituximab on primary non-Hodgkin lymphomas. Blood 101: $949-954$

Manshouri T, Do KA, Wang X, Giles FJ, O'Brien SM, Saffer H, Thomas D, Jilani I, Kantarjian HM, Keating MJ, Albitar M (2003) Circulating CD20 is detectable in the plasma of patients with chronic lymphocytic leukemia and is of prognostic significance. Blood 101: 2507-2513
Pommier Y, Sordet O, Antony S, Hayward RL, Kohn KW (2004) Apoptosis defects and chemotherapy resistance: molecular interaction maps and networks. Oncogene 23: $2934-2949$

Reff ME, Carner K, Chambers KS, Chinn PC, Leonard JE, Raab R, Newman RA, Hanna N, Anderson DR (1994) Depletion of B cells in vivo by a chimeric mouse human monoclonal antibody to CD20. Blood 83: 435-445

Selenko N, Maidic O, Draxier S, Berer A, Jager U, Knapp W, Stockl J (2001) CD20 antibody (C2B8)-induced apoptosis of lymphoma cells promotes phagocytosis by dendritic cells and cross-priming of CD8+ cytotoxic T cells. Leukemia 15: 1619-1626

Servitje O, Gallardo F, Estrach T, Pujol RM, Blanco A, Fernandez-Sevilla A, Petriz L, Peyri J, Romagosa V (2002) Primary cutaneous marginal zone B-cell lymphoma: a clinical, histopathological, immunophenotypic and molecular genetic study of 22 cases. Br J Dermatol 147: 1147-1158

Treon SP, Mitsiades C, Mitsiades N, Young G, Doss D, Schlossman R, Anderson KC (2001) Tumor cell expression of CD59 is associated with resistance to $\mathrm{CD} 20$ serotherapy in patients with B-cell malignancies. I Immunother 24: $263-271$

Vega MI, Huerta-Yepaz S, Garban H, Jazirehi A, Emmanouilides C, Bonavida B (2004) Rituximab inhibits p38 MAPK activity in 2F7 B NHL and decreases IL-10 transcription: pivotal role of p38 MAPK in drug resistance. Oncogene 23: 3530-3540

Willemze R, Jaffe ES, Burg G, Cerroni L, Berti E, Swerdlow SH, Ralfkiaer E, Chimenti S, Diaz-Perez JL, Duncan LM, Grange F, Harris NL, Kempf W, Kerl H, Kurrer M, Knobler R, Pimpinelli N, Sander C, Santucci M, Sterry W, Vermeer MH, Wechsler J, Whittaker S, Meijer CJ (2005) WHOEORTC classification for cutaneous lymphomas. Blood 105: $3768-3785$ 